\title{
Michał Muraszko \\ (Gniezno) \\ WYBRANE OPRAWY KSIĄG Z PRYWATNYCH BIBLIOTEK POLSKICH W ZBIORACH KANONIKA GNIEŹNIEŃSKIEGO TOMASZA JOSICKIEGO
}

\section{Abstract}

The article presents selected book bindings from the collection of a Gniezno canon, Tomasz Josicki, which originally belonged to three private libraries.

\section{Key words}

Tomasz Josicki, Kasper Rajman Starszy, Archdiocesan Archive in Gniezno, Cathedral Library in Gniezno, bindings, tegumentology 
Prace prowadzone w ramach projektu „Inwentaryzacja zasobu Biblioteki Katedralnej w Gnieźnie" pod kierunkiem dra Piotra Pokory (Uniwersytet im. Adama Mickiewicza w Poznaniu) pozwoliły, jak dotąd, na identyfikację przeszło 100 ksiąg należących do zbiorów T. Josickiego ${ }^{1}$.

Pochodził on ze Skotnik ${ }^{2}$. Był doktorem obojga praw, scholastykiem łuckim, kantorem wiślickim oraz plebanem w Świeciechowie. W latach 16021606 pełnił funkcję oficjała lubelskiego. W 1607 r. został kanonikiem gnieźnieńskim. Sprawował funkcję prokuratora dóbr kapitulnych oraz oficjała i wikariusza generalnego gnieźnieńskiego. Wraz z archidiakonem Wincentym de Seve ${ }^{3}$ nadzorował przepisanie "Liber beneficiorum” prymasa Jana Łaskiego. Był także współodpowiedzialny za opracowanie „Inventarium Ecclesiae Metropolitanae Gnesnensis". Ten dokument z 1608 r. zawiera między innymi katalog książek należących wówczas do Biblioteki Katedralnej. Po pożarze katedry w 1613 r. kierował pracami ratunkowymi. Wzniósł jedną z gnieźnieńskich kanonii. Zmarł 22 lipca 1616 r., pochowano go w katedrze w kaplicy, którą odrestaurował wraz z kanonikiem Wincentym Oczkiem ${ }^{4}$. Jego bogaty księgozbiór stał się odtąd własnością kościoła gnieźnieńskiego. Jeszcze przed II wojną światową mógł on liczyć przeszło 180 woluminów 5 . We wszystkich zinwentaryzowanych dotąd księgach z omawianej biblioteki znajdują się niemal jednakowo brzmiące wpisy proweniencyjne: „Ex libris Reverendi Domini Thomae Iossicii Iuris Utriusqve Doctoris Canonici Gnes-

\footnotetext{
${ }^{1}$ Projekt grantowy „Inwentaryzacja zasobu Biblioteki Katedralnej w Gnieźnie” finansowany jest z Narodowego Programu Rozwoju Humanistyki MNiSW (nr 11H 120179 81).

${ }^{2}$ Por. Z. Świechowski, L. Krzyżanowski, Nagrobki i epitafia, [w:] A. Świechowska (red.), Katedra gnieźnieńska, 1, Poznań et al. 1970, s. 223.

${ }^{3}$ Jak dotąd w trakcie prac inwentaryzacyjnych zidentyfikowano około 250 ksiąg należących do dawnej biblioteki archidiakona Wincentego de Seve.

${ }^{4}$ Por. I. Polkowski, Katedra Gnieźnieńska, Gniezno 1874, s. 22, 53-54, 188-189; J. Walkowski, Wspomnienia o kościele metropolitalnym w Gnieźnie o jego ołtarzach, kaplicach, pomnikach i osobach temi pomnikami zaszczyconych na pamiątkę dziewięćsetnej rocznicy jego istnienia napisane w roku 1865, Gniezno 1876, s. 32-33, 181-183; J. Korytkowski, Prałaci i kanonicy katedry metropolitalnej gnieźnieńskiej od roku 1000 aż do dni naszych. Podług źródeł archiwalnych, 2, Gniezno 1883, s. 193-194; T. Trzciński, Gniezno, [w:] Podręczna encyklopedia kościelna, 13-14, Warszawa 1907, s. 183; J. Wadowski, Kościoły lubelskie na podstawie źródeł archiwalnych, Kraków 1907, s. 61, p. 1; P. Hemperek, Oficjalat okręgowy w Lublinie XV-XVIII w. Studium z dziejów organizacji i kompetencji sądownictwa kościelnego, Lublin 1974, s. 220; J. Rył, Biblioteka Katedralna w Gnieźnie, Lublin 1978, s. 32, 50, 73 (oraz p. 322), 104, 106 (p. 92), 110, 131-132; L. Królik, Organizacja diecezji łuckiej i brzeskiej od XVI do XVIII wieku, Lublin 1983, s. 200; H. Kowalska, Sevé Wincenty de, [w:] Polski Słownik Biograficzny, 36, Warszawa-Kraków 1995-1996, s. 343-344; W. Froch, Dzieje Szkoły Lubelskiej przy kościele parafialnym św. Michała w XV-XVIII w., Lublin 1999, s. 91, 93; B.S. Kumor, Dzieje diecezji krakowskiej do roku 1795, 4, Kraków 2002, s. 116.

${ }^{5}$ J. Rył, Biblioteka, s. 73, p. 322.
} 
nensis etc. post mortem Ecclesiae Metropolitanae Gnesnensi iure legati 1616 22 Iulii”.

Przedmiotem niniejszych rozważań będą wybrane oprawy woluminów należących do zbiorów T. Josickiego. Księgi te posiadają znaki własnościowe bądź wpisy proweniencyjne informujące, że zanim trafiły do rąk gnieźnieńskiego kanonika, należały do innych prywatnych właścicieli.

Na przynależność pierwszego z woluminów do księgozbioru Andrzeja, członka rodziny Zetów Naramowskich ${ }^{6}$, wskazuje umieszczony na jego oprawie superekslibris napisowy z inicjałami „A Z” (oraz datą „1540”), a także wpisane na kartach druku i wyklejki trzy noty proweniencyjne: „A Z”, „Sum Andreae Naramowski emptus anno 1540”, „Sum Andreae Naramowski 1540 ”" Książka nie stanowiła z pewnością własności poznańskiego kanonika katedralnego Andrzeja Zeta Naramowskiego. Zmarł on bowiem przed 4 kwietnia $1537 \mathrm{r}^{8}$ Warto dodać, że imię to nosili także dwaj wnukowie braci wspomnianego dostojnika kościelnego 9 .

Oprawa, będąca przedmiotem niniejszych rozważań, zabezpiecza bazylejski druk z 1539 r. Została ona sporządzona z fazowanych desek bukowych, które powleczono białą lub kremową skórą i zaopatrzono w mosiężno-skórzane zapinki. Wszystkie zdobienia opracowano metodą wycisków na ślepo. Kompozycja górnej i dolnej okładziny opiera się na ramie utworzonej przy pomocy radełka i strychulca. Na wyciski pierwszego z narzędzi składają się wyobrażenia cnót, które przeplata ornament kandelabrowo-roślinny oraz tabliczki z podpisami poszczególnych postaci i datą „1539”. Wąskie zwierciadło górnej okładziny ujęto w cztery listwy. W górną wkomponowano superekslibris napisowy, składający się z inicjałów „A Z”, które rozgranicza wycisk tłoka z wyobrażeniem rozetki. W dolnej listwie umieszczono datę „1540”, informującą zapewne o roku sporządzenia oprawy. Listwy boczne przyozdo-

${ }^{6}$ Zob. M.J. Mika, Studia nad patrycjatem poznańskim, Poznań 2006, s. 13-21; A. Gąsiorowski, Naramowski Jerzy h. Łodzia, [w:] Polski Słownik Biograficzny, 22, Wrocław et al. 1977, s. 528-529; idem, Naramowski-Zyt Jerzy, [w:] Wielkopolski Słownik Biograficzny, Warszawa-Poznań 1981, s. 507-508; K. Górska-Gołaska, Naramowice, [w:] A. Gąsiorowski (red.), Słownik historycznogeograficzny województwa poznańskiego w średniowieczu, 3, 2, Poznań 1995, s. 235-240; Naramowscy h. Łodzia, [w:] Teki Dworzaczka. Materiały historyczno-genealogiczne do dziejów szlachty wielkopolskiej XV-XX wieku [online]. BKPAN [dostęp: 2014-11-16]. Dostępny w Internecie: $<$ http://teki.bkpan.poznan.pl/search.php?section=3\&single=1\&fileno=22\&page $=13>$.

${ }^{7}$ Archiwum Archidiecezjalne Gniezno, sygn. PL101.

${ }^{8}$ Receptiones seu installationes ad episcopatum, praelaturas et canonicatus Ecclesiae Cathedralis Posnaniensis ab anno 1532 usque ad annum 1800, R. Weimann (wyd.), Roczniki Towarzystwa Przyjaciół Nauk Poznańskiego 35, 1909, k. 22; M.J. Mika, Studia, s. 19; J. Nowacki, Dzieje archidiecezji poznańskiej, 1, Poznań 1959, s. 248, 437, 546, 725 (oraz p. 88).

${ }^{9}$ Por. M.J. Mika, Studia, s. 14. 
biono naprzemiennie rozłożonymi wyciskami, ukazującymi rozetkę oraz tzw. listek aldyński. Całą powierzchnię zwierciadła udekorowano natomiast tłokami, których wyciski prezentują mniejszą rozetkę oraz motyw kwiatu $\mathrm{w}$ kielichu ${ }^{10}$. W analogiczny sposób opracowano zdobienia okładziny dolnej. Miejsce superekslibrisu oraz daty zajmują tutaj jednak wyciski tłoków floralnych. Z kolei zwierciadło udekorowano bez użycia narzędzia z wyobrażeniem mniejszej rozetki.

Prezentowany egzemplarz powstał, zgodnie $\mathrm{z}$ umieszczoną na nim datą, w $1540 \mathrm{r}^{11}$ Łudząco podobny przerys wycisku radełka $\mathrm{z}$ wyobrażeniami cnót znajduje się w tzw. Einbanddatenbank. W odróżnieniu od tego, który umieszczono na „gnieźnieńskiej” oprawie, pojawiają się tutaj inicjały „C G”. Autorzy bazy łączą ten monogram $\mathrm{z}$ wittenberskim introligatorem Casparem Genselerem $^{12}$. Nie sposób obecnie stwierdzić, jak T. Josicki stał się właścicielem prezentowanego woluminu. Mogło to mieć miejsce zarówno przed, jak i po objęciu przez niego gnieźnieńskiej kanonii w $1607 \mathrm{r}$.

Kolejna księga, zanim trafiła do T. Josickiego, należała do krakowskiego dominikanina Grzegorza Cuneciusa ${ }^{13}$. Zakonnik miał studiować w latach 70. XVI stulecia w Bolonii ${ }^{14}$. W rozprawie „Propago D. Hyacinthi thaumaturgi Poloni" wspomina o nim Abraham Bzowski ${ }^{15}$.

Wenecki druk z 1569 r. zabezpiecza oprawa sporządzona z fazowanych desek bukowych, które zostały obciągnięte brązową skórą i zaopatrzone w mosiężno-skórzane zapinki. Jej okładziny ozdobiono metodą ślepego i złoconego wycisku przy użyciu strychulca, dwóch radełek, plakiety oraz tłoków. Dekoracja okładziny górnej opiera się na zewnętrznej ramie, w której

${ }^{10} \mathrm{Za}$ pomoc we właściwym nazwaniu tego motywu autor składa podziękowanie dr. Arkadiuszowi Wagnerowi.

${ }^{11} \mathrm{Na}$ podstawie niekompletnego (przyciętego) znaku wodnego, który przedstawia fragment korony diademowej, można przypuszczać, że papier, z którego sporządzono wyklejki woluminu, pochodzi $\mathrm{z}$ jednego $\mathrm{z}$ niemieckich młynów papierniczych. Liczne przykłady przerysów zbliżonych filigranów por. np. [online]. Piccard [dostęp: 2015-08-17]. Dostępny w Internecie: <http://www. piccard-online.de/struktur.php>.

${ }^{12}$ Zob. Zitiernummer EBDB r000099 [online]. Einbanddatenbank [dostęp: 2014-11-17]. Dostępny w Internecie: $<$ http://www.hist-einband.de/recherche/ebwerkz.php? rwz=b\&id=105409b $>$.

${ }^{13}$ AA Gniezno, sygn. BK991; zob. P. Pokora, M. Muraszko, Skarby drukarstwa i introligatorstwa ze zbiorów dawnej Biblioteki Katedralnej w Gnieźnie. Katalog wystawy w Bibliotece Raczyńskich, Poznań 5-30 maja 2015, Poznań-Gniezno 2015, s. 20.

${ }^{14}$ R. Świętochowski, A. Chruszczewski, Polonia Dominicana apud extraneos, [w:] J. Kłoczowski (red.), Studia nad historią dominikanów w Polsce 1222-1972, 2, Warszawa 1975, s. 478.

${ }^{15}$ A. Bzowski, Propago D. Hyacinthi thaumaturgi Poloni, Venetiis 1606, s. 89; K. Estreicher, Bibliografia polska, 13, Kraków 1894, s. 498-499; por. K. Mecherzyński, Historia wymowy w Polsce, 2, Kraków 1858, s. 459. 
umieszczono wyciski z tzw. radełka jagiellońskiego ${ }^{16}$. Przedstawiają one medaliony popiersiowe $\mathrm{z}$ wizerunkami przedstawicieli dynastii, okolone wieńcem laurowym z przewiązkami na osiach. Wyobrażenia poszczególnych członków rodziny królewskiej oddziela tutaj arabeska z motywem uskrzydlonych główek anielskich oraz prostokątne tabliczki z napisami identyfikacyjnymi. Wąskie wyciski radełka $z$ ornamentem plecionkowym ograniczają powierzchnię zwierciadła, którego wewnętrzne i zewnętrzne narożniki zdobią wyciski z dwóch tłoków o motywach floralnych. Centrum zwierciadła udekorowano plakietą, której owalny wycisk przedstawia popiersie Chrystusa Salwatora $^{17}$. Powyżej tego elementu dekoracyjnego znajduje się majuskulny napis informujący o treści oprawionego druku. Całości dopełniają wyciski z tłoka o motywie floralnym, które umieszczono na dłuższej osi zwierciadła, oraz wyciski przedstawiające czteroramienną gwiazdę. Analogicznie przyozdobiono dolną okładzinę oprawy. Miejsce wycisku owalnej plakiety zajmuje tutaj jednak superekslibris introligatorski. Sporządzono go prawdopodobnie przy pomocy dwóch tłoków. Wycisk z większego przedstawia dwustrefowy pierścień. Jego zewnętrzną część stanowi wieniec laurowy z przewiązkami i rozetkami na osiach. Natomiast w wewnętrzna wpisano dewizę: „PETE INFIMA TVRBVLENTA QVAEQVE ALTIORA"18. Pośrodku pierścienia osobnym tłokiem wyciśnięto rollwerkową tarczę z herbem Jastrzębiec. Powyżej oraz poniżej superekslibrisu introligatorskiego znajduje się napis: „F GREGO. CVNECIVS 1580 CONVEN. CRACO”. Całości dopełniają wyciski z tłoka przedstawiające czteroramienną gwiazdę. Niewielki fragment zachowanego filigranu nie pozwala niestety na identyfikację młyna, z którego pochodzi papier użyty przez introligatora do sporządzenia wyklejki ${ }^{19}$.

\footnotetext{
${ }^{16} \mathrm{Nt}$. tzw. radełek jagiellońskich zob. M. Jarosławiecka-Gąsiorowska, Ikonografia świecka na oprawach XVI i XVII w., Rocznik Biblioteki Narodowej 6, 1970, s. 323-337; eadem, Radełka jagiellońskie, [w:] Encyklopedia wiedzy o książce, Wrocław 1971, kol. 2048-2049; A. Wagner, Radełka jagiellońskie - fenomen introligatorstwa polskiego XVI-XVII w., Spotkania z Zabytkami 5-6, 2010, s. 70-71.

${ }^{17}$ Napis w otoku nieczytelny.

${ }^{18}$ Zbliżony wycisk w kształcie owalnego pierścienia, stanowiący element superekslibrisu introligatorskiego, znajduje się np. na górnej okładzinie oprawy woluminu przechowywanego w Archiwum Narodowym w Krakowie, Akta Miasta Krakowa, rkps 208, Acta officii advocatialis Cracoviensis, 1588 [znana autorowi $\mathrm{z}$ fotografii].

${ }^{19}$ Przyporządkowanie znaku wodnego z wyklejki do konkretnej papierni pozwala czasem na postawienie przypuszczenia, w jakim kręgu introligatorskim powstała dana oprawa; por. A. Wagner, Introligatorstwo poznańskie XVI wieku jako historyczno-artystyczna terra incognita, [w:] M. Błaszczyński, B. Górecka, M. Górecki, A. Paradowska (red.), Sztuka w Wielkopolsce, Poznań 2013, s. 71 .
} 
Staranne wykonanie zdobień okładziny dolnej omawianej oprawy kontrastuje z niedbale opracowaną dekoracją zwierciadła górnej okładziny. Owalny wycisk plakiety został tutaj bowiem odbity dwukrotnie. Początkowo rzemieślnikowi nie udało się przyłożyć narzędzia w taki sposób, aby wycisk znalazł się w samym centrum zwierciadła. Skorygowano to przy następnym podejściu. Po nieudanej próbie pozostał jednak dobrze widoczny ślad.

Prezentowana oprawa powstała, zgodnie $z$ wyciśniętą na jej dolnej okładzinie datą, w 1580 r. Można przypuszczać, że pochodzi ona z krakowskiej pracowni Kaspra Rajmana Starszego. Wyciski ze wspomnianego radełka jagiellońskiego sporządzono bowiem $\mathrm{z}$ narzędzia, którym udekorowano również oprawy ksiąg należących do prymasa Wojciecha Baranowskiego ${ }^{20}$. Wyobrażeniom członków rodziny panującej towarzyszą tam zdobienia wykonane $\mathrm{z}$ innych radełek. Przedstawiają one między innymi postaci czterech greckich muz i mężczyzny. Wyciski z tego samego narzędzia znajdują się na okładzinach oprawy zabezpieczającej tom "Regestra perceptorum et distributorum proventuum civitatis Cracoviensis” $\mathrm{z}$ drugiego półrocza $1587 \mathrm{r}^{21}$ Reprodukcję oraz dokładny opis tej oprawy zamieścił w jednej ze swych prac Adam Chmiel, który przypisał ją do warsztatu K. Rajmana Starszego. Rzemieślnik ten osiedlił się w Krakowie w 1566 r. Był starszym tutejszego cechu introligatorskiego. Oprawiał między innymi księgi radzieckie dla Krakowa i Kazimierza. Zmarł około 1600 lub 1603 r. $^{22}$

Wenecki druk, który zabezpiecza omawiana oprawa, został być może nabyty przez G. Cuneciusa w czasie jego pobytu w Italii. Nie wiadomo, w jaki sposób książka stała się własnością T. Josickiego. Można przypuszczać, że miało to miejsce przed uzyskaniem przez niego gnieźnieńskiej kanonii w 1607 r., a zatem w okresie, gdy był jeszcze bliżej związany z diecezją łucką lub krakowską.

\footnotetext{
${ }^{20}$ Np. por. AA Gniezno, sygn. BK1600, BK1603. Nie można oczywiście wykluczyć możliwości, że w momencie sporządzania prezentowanej oprawy (1580 r.) omawiany egzemplarz radełka jagiellońskiego stanowił własność innej introligatorni.

${ }^{21}$ AN Kraków, Akta Miasta Krakowa, rkps 1652, Regestra perceptorum et distributorum proventuum civitatis Cracoviensis, 1587 [znana autorowi $\mathrm{z}$ fotografii].

${ }^{22}$ A. Chmiel, Oprawy introligatora krakowskiego Kaspra Rajmana (Starszy) 1566-1600, Przemysł i Rzemiosło, 1, 1, 1921, s. 14-20; por. Cracovia impressorum XV et XVI saeculorum, J. Ptaśnik (opr.), Monumenta Poloniae typographica XV et XVI saeculorum, 1, Lwów 1922, s. 274, p. 2; K. Hałaciński, Introligatorzy krakowscy, obrońcami miasta, Kraków 1930, s. 9-10; E. Dudzińska, Rajman Kasper, [w:] I. Treichel (red.), Słownik pracowników książki polskiej, Warszawa-Łódź 1972, s. 744; J. Bieniarzówna, Rajman Kasper, [w:] Polski Słownik Biograficzny, 30, Wrocław et al. 1987, s. 485-486; J. Wasilewska, Oprawy inkunabułów (wydrukowanych w Wenecji) znajdujących się w zbiorach Biblioteki Uniwersyteckiej KUL, Archiwa, Biblioteki i Muzea Kościelne 72, 1999, s. 290-291.
} 
Kolejne trzy księgi z biblioteki T. Josickiego posiadają noty własnościowe informujące, że stanowiły pierwotnie własność ks. Szymona z Urzędowa ${ }^{23}$. Postać tę można łączyć z kapelanem biskupa łuckiego Bernarda Maciejowskiego oraz plebanem w Sokołowie Podlaskim (od 1592 r.) i Skrzeszewie ${ }^{24}$.

Trzy oprawy, będące przedmiotem niniejszych rozważań, zabezpieczają zbiór homilii Ludwika z Granady. Druki te, pochodzące z antwerpskiej oficyny Krzysztofa Plantina, zostały oprawione, zanim trafiły do zbiorów T. Josickiego. Wpis własnościowy, informujący o nabyciu przez ks. Szymona z Urzędowa (w 1584 r.) pięciu tomów dzieła słynnego dominikanina, znajduje się bowiem na wewnętrznej stronie górnej okładziny jednego $\mathrm{z}$ woluminów ${ }^{25}$. $\mathrm{Z}$ noty proweniencyjnej wiadomo, że duchowny zakupił książki w Brzozowie, miejscowości, w której rezydowali przemyscy biskupi ${ }^{26}$.

Fazowane deski, z których wykonano oprawy, zostały obciągnięte brązową skórą i zaopatrzone w mosiężno-skórzane zapinki. Ich zdobienia sporządzono przy wykorzystaniu strychulca, plakiety, tłoków o motywach floralnych, tłoków literniczych oraz radełek. Dekoracje górnych okładzin opracowano niemal w całości metodą wycisku na złoto. Kompozycja każdej z nich została oparta na wąskiej ramie, w którą wkomponowano wyciski radełka z ornamentem plecionkowym. Centrum szerokiego zwierciadła zajmuje wycisk owalnej plakiety z popiersiem Chrystusa Salwatora ${ }^{27}$. Powyżej oraz poniżej tego elementu umieszczono majuskulny napis dotyczący drukowanego dzieła. Każdorazowo całości dopełniają wyciski z tłoków o motywach floralnych. W przypadku opraw zabezpieczających druki z 1579 oraz 1581 r. dekoracje dolnych okładzin zostały opracowane metodą ślepego wycisku strychulcem oraz jednym radełkiem (przy ich pomocy utworzono ramę oraz dwa równoległe, pionowe pasy w zwierciadle $)^{28}$. Wyciski z tego ostatniego przed-

${ }^{23}$ AA Gniezno, sygn. BK496, BK575, BK583.

${ }^{24} \mathrm{Za}$ pomoc $\mathrm{w}$ dotarciu do informacji o Szymonie $\mathrm{z}$ Urzędowa autor składa podziękowanie ks. prał. dr. Zbigniewowi Rostkowskiemu, ks. prał. mgr. lic. Bernardowi Błońskiemu oraz dr. Tomaszowi Jaszczołtowi; por. Archiwum Diecezjalne Siedlce, Akta Konsystorza Janowskiego, sygn. D 16, k. 5v.; T. Jaszczołt, Osadnictwo lewobrzeżnej części ziemi drohickiej w XV i na początku XVI wieku - okolice Sokołowa, Węgrowa i Mord, [w:] G. Ryżewski (red.), Sokołów Podlaski. Dzieje miasta i okolic, Białystok-Sokołów Podlaski 2006, s. 78; G. Ryżewski, Pod panowaniem możnych rodów w XVI-XVIII w., [w:] ibidem, s. 250.

${ }^{25}$ Por. AA Gniezno, sygn. 575; za pomoc w odczytaniu noty proweniencyjnej oraz wszelkie inne cenne uwagi autor składa podziękowanie mgr. Jakubowi Łukaszewskiemu.

${ }^{26}$ J. Rąb, Z dziejów Brzozowa w XIV-XVIII w., [w:] J.F. Adamski et al. (red.), Brzozów. Zarys monograficzny, Brzozów 1990, s. 65-68.

${ }^{27}$ Napis w otoku: „IESVS CHRISTVS FILIVS DEI VIVI SALVATOR MVNDI REX REGVM ET DOMINVS DOMINANTI".

${ }^{28}$ AA Gniezno, sygn. BK496, BK575. 
stawiają medaliony popiersiowe okolone wieńcem laurowym. Powierzchnie pomiędzy poszczególnymi przedstawieniami wypełnia ornament kandelabrowo-roślinny. Dla ozdobienia dolnej okładziny oprawy, chroniącej druki z 1580 r., użyto radełka, którego wyciski przedstawiają medaliony z popiersiami antycznych wojowników ${ }^{29}$. Przy użyciu tego narzędzia sporządzono ramę oraz trzy równoległe, pionowe pasy w zwierciadle.

Znaki wodne znajdujące się na wyklejkach omawianych woluminów, prezentujące herb Jastrzębiec, należy przypisać młynowi w podkrakowskich Grembienicach $^{30}$. Użycie papieru $\mathrm{z}$ tym filigranem może wskazywać na małopolskiego introligatora. Wydaje się, że również te oprawy pochodzą $\mathrm{z}$ krakowskiego warsztatu K. Rajmana Starszego ${ }^{31}$. Świadczą o tym zdobienia ich dolnych okładzin, wykonane przy użyciu dwóch radełek. Wyciski z tych samych narzędzi można znaleźć na egzemplarzach należących do prymasa W. Baranowskiego ${ }^{32}$. Radełkiem, którym przyozdobiono okładziny opraw druków z 1579 oraz 1581 r., udekorowano również obiekt omówiony przez A. Chmiela ${ }^{33}$.

Trudno jednoznacznie stwierdzić, w jakich okolicznościach przedstawiane woluminy stały się własnością T. Josickiego. Zarówno Sokołów Podlaski, jak i Skrzeszew, gdzie Szymon z Urzędowa był plebanem, leżały w obrębie diecezji łuckiej. Na bliski związek T. Josickiego z B. Maciejowskim jako biskupem tej diecezji wskazuje epitafium kanonika umieszczone $\mathrm{w}$ jednej z kaplic gnieźnieńskiej katedry, jak również fakt, że był on scholastykiem łuckim ${ }^{34}$. Również Szymon z Urzędowa, będąc kapelanem hierarchy, musiał zaliczać się do jego bliskiego otoczenia. Możliwe, że egzemplarze przeszły na własność T. Josickiego bezpośrednio od sokołowskiego plebana. Jako okres wykonania trzech omówionych opraw można przyjąć przedział od 1579 do $1584 \mathrm{r}$.

\footnotetext{
${ }^{29}$ AA Gniezno, sygn. BK583.

${ }^{30}$ Por. Papiernie w Polsce XVI wieku. Prace Franciszka Piekosińskiego, Jana Ptaśnika, Kazimierza Piekarskiego. Powtórnie wydał i uzupełnił Włodzimierz Budka, Wrocław et al. 1971, 128$-129,136-138$.

${ }^{31} \mathrm{~W}$ trakcie prowadzonych prac inwentaryzacyjnych natrafiono na dwie oprawy o bardzo zbliżonych dekoracjach okładzin (AA Gniezno, sygn. BK537, BK540). Również one pochodzą prawdopodobnie z pracowni K. Rajmana Starszego. Wydaje się, że przy pomocy tych samych narzędzi introligatorskich sporządzono również dekorację oprawy woluminu przechowywanego obecnie w zbiorach Biblioteki Poznańskiego Towarzystwa Przyjaciół Nauk (sygn. 22435. I); por. Baza Opraw Zabytkowych XV-XVIII w. [online]. PTPN [dostęp: 2014-11-15]. Dostępny w Internecie: $<$ http://www.ptpn.ig.pl/oprawy>.

${ }^{32} \mathrm{~Np}$. por. AA Gniezno, sygn. BK970, BK1265.

${ }^{33}$ A. Chmiel, Oprawy, s. 14-20.

${ }^{34}$ Por. I. Polkowski, Katedra, s. 188-189; J. Walkowski, Wspomnienia, s. 182, p. 1; J. Korytkowski, Prałaci, 2, s. 194; Z. Świechowski, L. Krzyżanowski, Nagrobki, s. 223; L. Królik, Organizacja, s. 200.
} 
Do zaprezentowanych woluminów należy doliczyć kolejne księgi, które trafiły do T. Josickiego z innych prywatnych bibliotek. Cztery z nich posiadają, pozbawione jakiejkolwiek dekoracji, oprawy pergaminowe $\mathrm{e}^{35}$. Jedna została natomiast przeoprawiona w XVIII lub XIX stuleciu ${ }^{36}$. Analiza dotychczas zinwentaryzowanych woluminów z księgozbioru gnieźnieńskiego kanonika pozwala na postawienie kilku wniosków. Pomniejszą część omawianej biblioteki stanowiły książki, które należały pierwotnie do co najmniej kilku innych prywatnych zbiorów. Można przypuszczać, że niektóre z nich T. Josicki otrzymał, już oprawione, bezpośrednio od ich właścicieli ${ }^{37}$. Wśród opraw pojawiają się zarówno te kosztowniejsze, sporządzone z desek obciągniętych skórą, jak również tańsze, wykonane z pergaminu. Należy zwrócić uwagę, że T. Josicki nie usuwał śladów mogących wskazywać na poprzednich właścicieli ksiąg, np. poprzez niszczenie superekslibrisów czy wycinanie lub zakreślanie not proweniencyjnych ${ }^{38}$. Kanonik nie nadawał również woluminom cech własnościowych, które informowałyby, że należą one odtąd do jego zbiorów. Dobrym przykładem takiego postępowania może być księga opata wągrowieckiego Andrzeja Dzierżanowskiego (zm. 1583 r.). Duchowny ten kazał oznaczyć ją swym superekslibrisem, który umieszczono w zwierciadle okładziny górnej. Dolną okładzinę zdobi tutaj tymczasem superekslibris napisowy pierwszego właściciela, którym był Benedykt Herbest (zm. 1598 r.) ${ }^{39}$. Dekoracja większości spośród zaprezentowanych opraw posiada wymowę kontrreformacyjną, sprowadzającą się do wycisków plakiet z wyobrażeniem Chrystusa Salwatora ${ }^{40}$. Warto również zwrócić uwagę, że T. Josicki posiadał woluminy oprawione prawdopodobnie w pracowni K. Rajmana Starszego, będąc zarówno ich pierwszym, jak również wtórnym właścicielem ${ }^{41}$.

${ }^{35}$ AA Gniezno, sygn. BK54, BK202, BK1206, BK1557.

${ }^{36}$ AA Gniezno, sygn. BK102.

${ }^{37}$ Nota proweniencyjna na karcie tytułowej weneckiego druku z 1570 r. świadczy, że T. Josicki otrzymał wolumin (zapewne już oprawiony) od dziekana i plebana łekneńskiego Piotra Parznickiego (zm. 1627); por. AA Gniezno, sygn. BK1557.

${ }^{38}$ Wśród zinwentaryzowanych dotąd książek gnieźnieńskiego kanonika zakreślona i częściowo starta nota proweniencyjna znajduje się jedynie na karcie tytułowej weneckiego druku z $1570 \mathrm{r}$. Wydaje się, że T. Josicki był czwartym z kolei właścicielem tego woluminu; por. ibidem.

${ }^{39}$ AA Gniezno, sygn. BK1599; por. L. Formanowicz, Katalog inkunabułów biblioteki kapitulnej w Gnieźnie, 1, Gniezno 1939, s. 22-23, 75; L. Grajkowska, Biblioteka klasztorna cystersów w Wągrowcu, Studia Gnesnensia 6, 1981, s. 212-213.

${ }^{40}$ Por. A. Wagner, Introligatorstwo, s. 77.

${ }^{41}$ M. Muraszko, Oprawa „Theatrum seu potius officina concionatorum...” z księgozbioru kanonika gnieźnieńskiego Tomasza Josickiego, [w druku]. 


\section{Michał Muraszko}

SELECTED BINDINGS OF VOLUMES FROM PRIVATE POLISH LIBRARIES, FOUND IN THE COLLECTION OF THE GNIEZNO CANON, TOMASZ JOSICKI

\section{Summary}

The article discusses selected bindings of books which belonged to the abundant collection of a Gniezno canon, Tomasz Josicki (died 1616). The volumes had earlier been the property of Szymon z Urzędowa, Grzegorz Cunecius and Andrzeja Zet Naramowski. Among other things, the texts presents the embellishments of their covers, which in most cases have a counter-reformatory overtone, conveyed by the impressions of plaques with the bust of Christ as Salvator Mundi. Four of the discussed specimens were most likely made in the workshop of a Cracow bookbinder, Kasper Rajman Starszy. 
MICHAŁ MURASZKO, WYBRANE OPRAWY KSIĄG Z PRYWATNYCH BIBLIOTEK POLSKICH

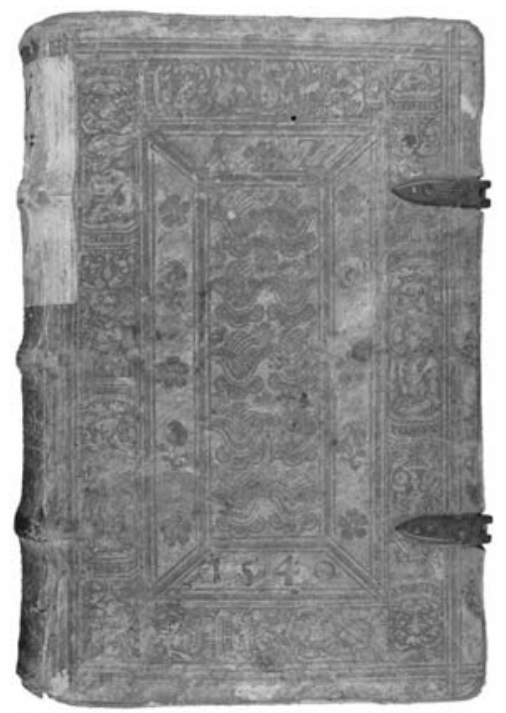

Il. 1. Górna okładzina oprawy bazylejskiego druku z 1539 r. (AA Gniezno, sygn. PL101), fot. M. Muraszko

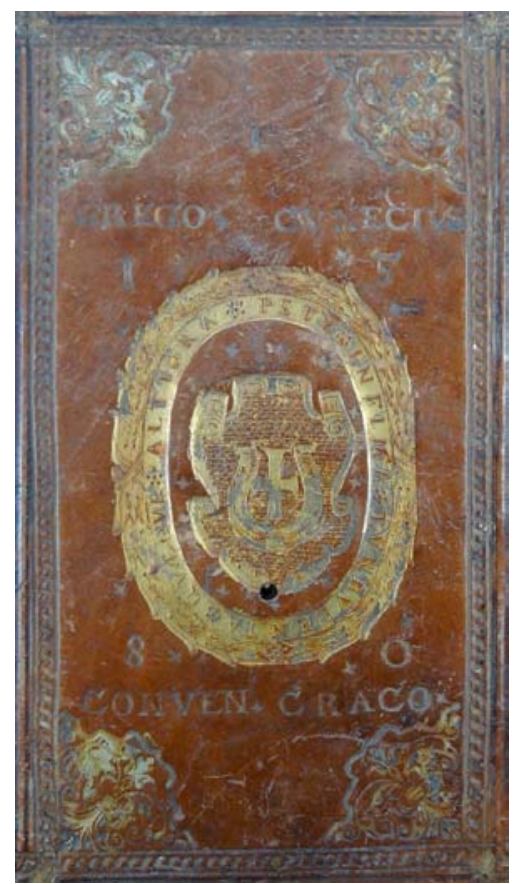

Il. 2. Superekslibris G. Cuneciusa na oprawie weneckiego druku z 1569 r. (AA Gniezno, sygn. BK991), fot. M. Muraszko 


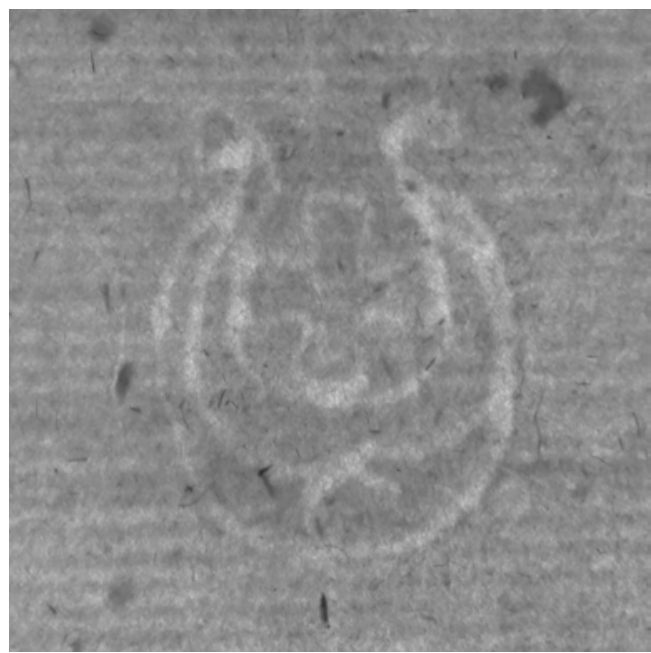

Il. 3. Znak wodny na wyklejce woluminu ze zbiorów ks. Szymona z Urzędowa (AA Gniezno, sygn. BK575), fot. M. Muraszko

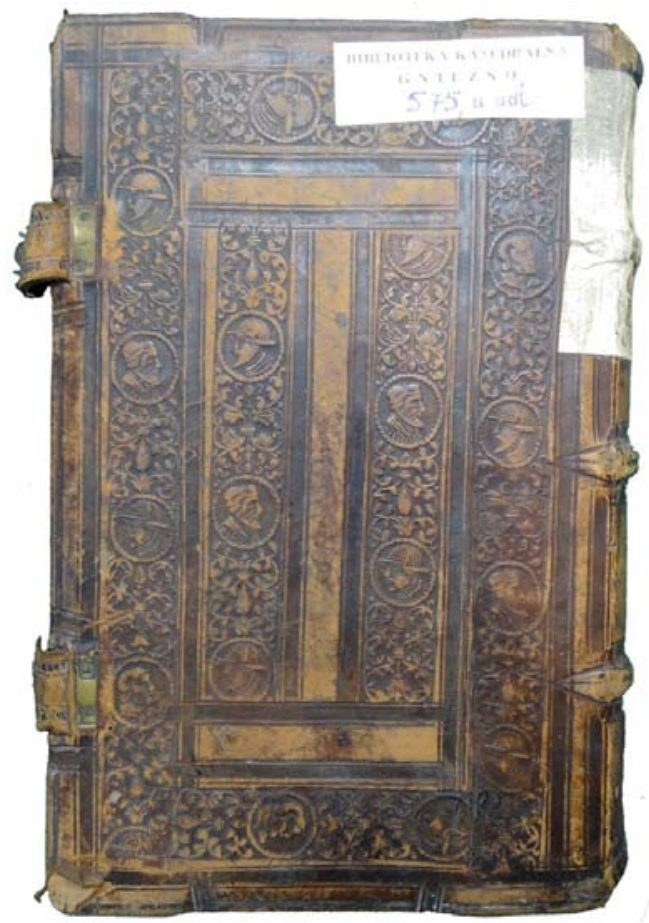

Il. 4. Dolna okładzina oprawy woluminu ze zbiorów ks. Szymona z Urzędowa (AA Gniezno, sygn. BK575), fot. M. Muraszko 


\section{Bibliografia}

Wykaz źródeł

Archiwum Archidiecezjalne Gniezno, sygn: BK54, BK102, BK202, BK496, BK537, BK540, BK575, BK583, BK970, BK991, BK1206, BK1265, BK1557, BK1599, BK1600, BK1603, PL101.

Archiwum Diecezjalne Siedlce, Akta Konsystorza Janowskiego, sygn. D 16.

Archiwum Narodowe Kraków, Akta Miasta Krakowa, rkps: 208, 1652.

Baza Opraw Zabytkowych XV-XVIII w. [online]. PTPN [dostęp: 2014-11-15]. Dostępny w Internecie: <http://www.ptpn.ig.pl/oprawy>.

Zitiernummer EBDB r000099 [online]. Einbanddatenbank [dostęp: 2014-11-17]. Dostępny w Internecie: <http://www.hist-einband.de/recherche/ebwerkz.php?rwz=b\&id=105409b $>$.

Opracowania

Bieniarzówna J., Rajman Kasper, [w:] Polski Słownik Biograficzny, 30, Wrocław et al. 1987, s. $485-486$.

Bzowski A., Propago D., Hyacinthi thaumaturgi Poloni, Venetiis 1606.

Chmiel A., Oprawy introligatora krakowskiego Kaspra Rajmana (Starszy) 1566-1600, Przemysł i Rzemiosło, 1, 1, 1921, s. 14-20.

Cracovia impressorum XV et XVI saeculorum, opr. J. Ptaśnik, Monumenta Poloniae typographica XV et XVI saeculorum, 1, Lwów 1922.

Dudzińska E., Rajman Kasper, [w:] I. Treichel (red.), Słownik pracowników książki polskiej, Warszawa-Łódź 1972, s. 744.

Estreicher K., Bibliografia polska, 13, Kraków 1894.

Formanowicz L., Katalog inkunabułów biblioteki kapitulnej w Gnieźnie, 1, Gniezno 1939.

Froch W., Dzieje Szkoły Lubelskiej przy kościele parafialnym św. Michała w XV-XVIII w., Lublin 1999.

Gąsiorowski A., Naramowski Jerzy h. Łodzia, [w:] Polski Słownik Biograficzny, 22, Wrocław et al. 1977, s. 528-529.

Gąsiorowski A., Naramowski-Zyt Jerzy, [w:] Wielkopolski Słownik Biograficzny, WarszawaPoznań 1981, s. 507-508.

Górska-Gołaska K., Naramowice, [w:] A. Gąsiorowski (red.), Słownik historyczno-geograficzny województwa poznańskiego w średniowieczu, 3, 2, Poznań 1995, s. 235-240.

Grajkowska L., Biblioteka klasztorna cystersów w Wągrowcu, Studia Gnesnensia 6, 1981, s. 209-220.

Hałaciński K., Introligatorzy krakowscy, obrońcami miasta, Kraków 1930.

Hemperek P., Oficjalat okręgowy w Lublinie XV-XVIII w. Studium z dziejów organizacji i kompetencji sądownictwa kościelnego, Lublin 1974.

Jarosławiecka-Gąsiorowska M., Ikonografia świecka na oprawach XVI i XVII w., Rocznik Biblioteki Narodowej 6, 1970, s. 315-337.

Jarosławiecka-Gąsiorowska M., Radełka jagiellońskie, [w:] Encyklopedia wiedzy o książce, Wrocław 1971, s. 2048-2049.

Jaszczołt T., Osadnictwo lewobrzeżnej części ziemi drohickiej w XV i na początku XVI wieku - okolice Sokołowa, Węgrowa i Mord, [w:] G. Ryżewski (red.), Sokołów Podlaski. Dzieje miasta i okolic, Białystok-Sokołów Podlaski 2006, s. 63-243.

Korytkowski J., Prałaci i kanonicy katedry metropolitalnej gnieźnieńskiej od roku 1000 aż do dni naszych. Podług źródeł archiwalnych, 2, Gniezno 1883.

Kowalska H., Sevé Wincenty de, [w:] Polski Słownik Biograficzny, 36, Warszawa-Kraków 1995-1996, s. 343-344.

Królik L., Organizacja diecezji łuckiej i brzeskiej od XVI do XVIII wieku, Lublin 1983.

Kumor B.S., Dzieje diecezji krakowskiej do roku 1795, 4, Kraków 2002.

Mecherzyński K., Historia wymowy w Polsce, 2, Kraków 1858. 
Mika M.J., Studia nad patrycjatem poznańskim, Poznań 2006.

Muraszko M., Oprawa „Theatrum seu potius officina concionatorum...” z księgozbioru kanonika gnieźnieńskiego Tomasza Josickiego, [w druku].

Naramowscy h. Łodzia, [w:] Teki Dworzaczka. Materiały historyczno-genealogiczne do dziejów szlachty wielkopolskiej XV-XX wieku [online]. BKPAN [dostęp: 2014-11-16]. Dostępny w Internecie: <http://teki.bkpan.poznan.pl/search.php?section=3\&single=1\&fileno=22\&page $=13>$.

Nowacki J., Dzieje archidiecezji poznańskiej, 1, Poznań 1959.

Papiernie w Polsce XVI wieku. Prace Franciszka Piekosińskiego, Jana Ptaśnika, Kazimierza Piekarskiego. Powtórnie wydał i uzupełnił Włodzimierz Budka, Wrocław et al. 1971.

Pokora P., Muraszko M., Skarby drukarstwa i introligatorstwa ze zbiorów dawnej Biblioteki Katedralnej w Gnieźnie. Katalog wystawy w Bibliotece Raczyńskich, Poznań 5-30 maja 2015, Poznań-Gniezno 2015.

Polkowski I., Katedra Gnieźnieńska, Gniezno 1874.

Rąb J., Z dziejów Brzozowa w XIV-XVIII w., [w:] J.F. Adamski et al. (red.), Brzozów. Zarys monograficzny, Brzozów 1990.

Receptiones seu installationes ad episcopatum, praelaturas et canonicatus Ecclesiae Cathedralis Posnaniensis ab anno 1532 usque ad annum 1800, wyd. R. Weimann, Roczniki Towarzystwa Przyjaciół Nauk Poznańskiego 35, 1909.

Rył J., Biblioteka Katedralna w Gnieźnie, Lublin 1978.

Ryżewski G., Pod panowaniem możnych rodów w XVI-XVIII w., [w:] G. Ryżewski (red.), Sokołów Podlaski. Dzieje miasta i okolic, Białystok-Sokołów Podlaski 2006, s. 245-332.

Świechowski Z., Krzyżanowski L., Nagrobki i epitafia, [w:] A. Świechowska (red.), Katedra gnieźnieńska, 1, Poznań et al. 1970, s. 197-274.

Świętochowski R., Chruszczewski A., Polonia Dominicana apud extraneos, [w:] J. Kłoczowski (red.), Studia nad historią dominikanów w Polsce 1222-1972, 2, Warszawa 1975, s. 467-572 .

Trzciński T., Gniezno, [w:] Podręczna encyklopedia kościelna, 13-14, Warszawa 1907, s. 175-185 .

Wadowski J., Kościoły lubelskie na podstawie źródeł archiwalnych, Kraków 1907.

Wagner A., Introligatorstwo poznańskie XVI wieku jako historyczno-artystyczna terra incognita, [w:] M. Błaszczyński, B. Górecka, M. Górecki, A. Paradowska (red.), Sztuka w Wielkopolsce, Poznań 2013, s. 68-86.

Wagner A., Radełka jagiellońskie - fenomen introligatorstwa polskiego XVI-XVII w., Spotkania z Zabytkami 5-6, 2010, s. 70-71.

Walkowski J., Wspomnienia o kościele metropolitalnym w Gnieźnie o jego ołtarzach, kaplicach, pomnikach i osobach temi pomnikami zaszczyconych na pamiątkę dziewięćsetnej rocznicy jego istnienia napisane w roku 1865, Gniezno 1876.

Wasilewska J., Oprawy inkunabułów (wydrukowanych w Wenecji) znajdujących się w zbiorach Biblioteki Uniwersyteckiej KUL, Archiwa, Biblioteki i Muzea Kościelne 72, 1999, s. 279-352. 